\title{
The 1755 earthquake in the Algarve (South of Portugal): what would happen nowadays?
}

\author{
F. Tedim Pedrosa and J. Gonçalves \\ Faculty of Arts of University of Porto, Portugal \\ Received: 15 June 2007 - Revised: 11 October 2007 - Accepted: 12 October 2007 - Published: 2 January 2008
}

\begin{abstract}
The 1755 Lisbon earthquake, which reached a magnitude of 8.5 , remains the most powerful and destructive to hit Europe so far. Within minutes, many lives were lost, populations displaced, livelihoods, homes and infrastructures were destroyed. Although frequently associated to the city of Lisbon, one of the most important European cities at the time, this earthquake caused similar damage and casualties, if not greater, in the southwest of the Algarve, where the seismic intensity was estimated at IX-X Mercalli Intensity Scale. Some time later a tsunami increased the number of victims and the amount of damage. In some locations the tsunami caused greater destruction than the earthquake itself. The tsunami hit both coasts of the North Atlantic; however, the more destructive damage occurred in the Portuguese coast, south from Lisbon, in the Gulf of Cadiz and in the Moroccan coast. The downtown of Lisbon was flooded by waves that reached a height of $6 \mathrm{~m}$. The water flooded an area with an extension of around $250 \mathrm{~m}$ from the coast. In the Southwest part of Algarve the waves reached a height between 10 and $15 \mathrm{~m}$ and the flooded area was much larger. Through the analysis of recent research works on the assessment of the 1755 tsunami parameters and the interpretation of the more reliable historical documents, it is our intention to analyse the destructive power of the tsunami in the Algarve and delimit the flooded area. Using simple techniques of simulation it is our intention to assess the impacts nowadays of the occurrence of a tsunami similar to the one that hit the Algarve in 1755, which would probably affect a greater number of people, buildings and infrastructures. This assessment is an important instrument not only in terms of disaster preparedness but also for the integration of risk mitigation measures in land use planning.
\end{abstract}

Correspondence to: F. Tedim Pedrosa

(fpedrosa@letras.up.pt)

\section{Introduction}

On the 1 November 1755 there was a magnitude 8.5 earthquake in Lisbon, one of the most important European cities of the time. This earthquake remains the most powerful and destructive to hit Europe so far. Although associated with the city of Lisbon, the earthquake caused similar or greater damage and casualties in the Algarve region located in the south of Portugal, where the seismic intensity was estimated at IXX on the Mercalli Intensity Scale (Sousa, 1919; Baptista et al., 1998; Chester, 2001).

The earthquake epicentre is known to have been offshore but the exact location remains a controversial and debated issue. The plate tectonics of the region are complex, with several independent blocks/plates, moving at slow relative motions and producing numerous structures showing signs of recent deformation (Gutscher, 2005).

There are several proposals of tectonic sources for the 1755 earthquake, for instance the Gorringe Bank (Johnston, 1996) a structure large enough to generate the earthquake, although incapable of producing a tsunami similar to that in 1755 (Costa et al., 2005); the Marquis of Pombal Fault (Zitelline et al., 2001); a potential composite source including the Marquis of Pombal Fault and the Guadalquivir Bank (Baptista et al., 2003); and most recently the subduction fault plane in the Gulf of Cadiz (Gutscher, 2004) that is a locked seismogenic zone with active subduction (Miranda et al., 2005) with sufficient dimensions (roughly $200 \times 200 \mathrm{~km}$ ) to generate an earthquake of moment magnitude $M=8.64$ with a co-seismic slip of $10 \mathrm{~m}$ and a recurrence interval of 2000 years (Gutscher, 2005). A combination of the subduction fault plane and an additional source further to the NW may offer the best explanation for the historically observed tsunami and seismic intensity patterns (Gutscher, 2005). It is now clear that the geodynamic context and the rupture mechanism of the 1755 earthquake are quite different from those implied in the 28 February 1969 earthquake, which also generate a tsunami (Table 1 ).

Published by Copernicus Publications on behalf of the European Geosciences Union. 
Table 1. The greatest earthquakes in Algarve.

\begin{tabular}{ccccl}
\hline Date & Latitude & Longitude & Estimated Magnitude & Occurrence of Tsunami \\
\hline $63 \mathrm{BC}$ & $36.0 \mathrm{~N}$ & $10.7 \mathrm{~W}$ & 8.5 & Probably a tsunami (Oliveira, 1986) \\
$47 \mathrm{BC}$ & $?$ & $?$ & 8.5 & \\
$33 \mathrm{BC}$ & $?$ & $?$ & 9.0 & \\
309 & $37.0 \mathrm{~N}$ & $11 \mathrm{~W}$ & 7.0 & \\
382 & $36.5 \mathrm{~N}$ & $9.5 \mathrm{~W}$ & 7.5 & There was a tsunami (Brito, 1597) \\
1309 & $36.0 \mathrm{~N}$ & $11.0 \mathrm{~W}$ & 7.0 & \\
1356 & $36.0 \mathrm{~N}$ & $10.7 \mathrm{~W}$ & 7.5 & \\
1504 & $38.7 \mathrm{~N}$ & $5.6 \mathrm{~W}$ & 7.0 & \\
1531 & $38.95 \mathrm{~N}$ & $9.0 \mathrm{~W}$ & 7.1 & \\
1719 & $37.1 \mathrm{~N}$ & $8.5 \mathrm{~W}$ & 7.0 & Tsunami \\
1722 & $36.9 \mathrm{~N}$ & $7.6 \mathrm{~W}$ & 7.0 & Tsunami \\
1755 & $?$ & $?$ & 8.5 & Tsunami - intensity II \\
1909 & $38.9 \mathrm{~N}$ & $8.8 \mathrm{~W}$ & 7.6 & \\
1969 & $36.2 \mathrm{~N}$ & $10.6 \mathrm{~W}$ & 7.5 & \\
\hline
\end{tabular}

Source: Martins and Mendes-Victor, 2001

In this paper, it is our purpose to delimitate the area flooded by the 1755 tsunami in the Algarve coast and to assess the impacts nowadays of the occurrence of a similar event. We selected as a case study the municipality of Portimão (Fig. 1), which was one of the most devastated.

We want to show that the determination of the flooded area is an important instrument not only in terms of disaster preparedness but also for the integration of mitigation measures in the strategy of development, land planning and management of the coastal area.

\section{Data and methodology}

Although the earthquake occurred in 1755 , the devastation is well documented in engravings, reports in newspapers of the time, and letters between several distinguished people. Prime Minister Melo ordered a survey, known as the Marquis of Pombal Survey, to be answered by the priests of all parishes of the kingdom and which contributed immensely to a scientific analysis of the earthquake, and the disaster response. However, because the answers to the Marquis of Pombal Survey regarding the Algarve remain unknown, we based our research mainly on another survey sent to all the parishes that included a question regarding the devastation level caused by the earthquake and the state of current reconstruction. Despite the questionnaire not including a question directly related with the tsunami, the priests mentioned in their answers the damage caused by it. This survey is known as the Dicionário Geográfico (Geographical Dictionary) of 1758 , although is much more limited for the study of the 1755 earthquake than the earlier Marquis of Pombal Survey.

The information collected in historical documents about the height of the waves and the extension of penetration of the tsunami on land provided a basis to the delimitation of the flooded area. However, we are not entirely sure of the exact coastal morphology of the time, so it is particularly important to determine the location of churches and other buildings damaged by the force of the waves, in which the maximum height of the water is known, in order to validate our methodology. A good example is the Igreja da Misericórdia, located ten meters above sea level. The water, inside this building, is said to have reached $2.64 \mathrm{~m}$ high. So the height of the wave was determined based in three types of information: historical description of the wave height, extension of penetration of the tsunami and reports of destroyed buildings.

Also important was the Digital Terrain Model (DTM) built for the municipality of Portimão. The determination of the flooded area depends on the accuracy of this model. The DTM was built based in topographic information at 1/5000 scale, resulting in a Triangulated Irregular Network.

After determining the probable height reached by the wave in certain areas of the municipality, we used the analysis capacity of Geographical Information Systems technology to determine the area likely to have been flooded in the 1755 tsunami. The next step was cross-referencing this information with the current data available regarding population, built-up area, and equipment using overlay operations.

\section{The historical data analysis}

The municipality of Portimão comprises the freguesias (parishes) of Alvor, Portimão and Mexilhoeira Grande (Fig. 2). The earthquake shaking reached the intensity VIII on the Mercalli Intensity Scale in Mexilhoeira Grande and X in Alvor and Portimão (Sousa, 1919; Chester, 2001).

According to historical references in Alvor the sea inundated $660 \mathrm{~m}$ inland, nearly reaching houses at $30 \mathrm{~m}$ altitude. The chapel of Nossa Senhora da Ajuda, located on the beach 


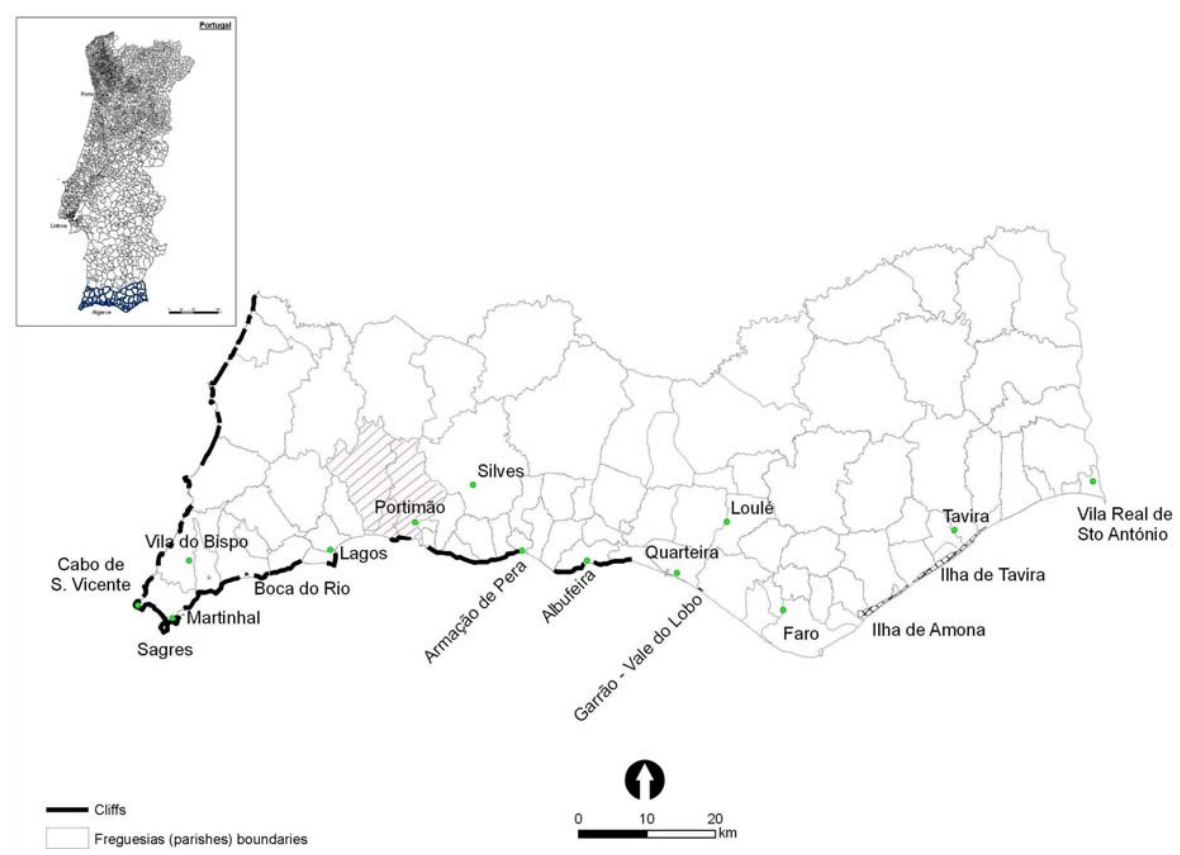

Fig. 1. The localisation of the municipality of Portimão.

by the harbour, was completely destroyed leaving no traces of its foundations (Lopes, 1841).

In the freguesia of Portimão the sea flowed inland, overtopping the natural barriers, in some areas more than $880 \mathrm{~m}$, devastating the salt ponds of this village. Since then no salt has been produced there (Dicionário Geográfico, 1758). The harbour of Portimão forms a great mouth berthed between two large rocks, in front of which are the fortresses of Santa Catarina and São João. The first of the two was severely damaged (Dicionário Geográfico, 1758) and the latter was completely washed out (Lopes, 1841).

Through the village of Portimão flowed successively amazing waves, which advanced over $5 \mathrm{~km}$ up the river. As the waves advanced everything was destroyed. Several boats were carried inland to such great distance that it was not possible to bring them back. Flooding occurred on the outskirts of the village, destroying all the houses and drowning many people, which had sought refuge in the river banks (Castro, 1786).

From the accounts about the height of the wave we verify that near the coast it must have got to $20 \mathrm{~m}$ high. It is said that the water reached the village of Alvor which is located between 20 to $30 \mathrm{~m}$ a.s.l., reaching the Fortress of Santa Catarina $(20 \mathrm{~m})$. The city of Portimão is protected by the rocks of Praia da Rocha, so it is probable that the wave did not reach the height of $20 \mathrm{~m}$. The Igreja da Misericórdia is the main source for the determination of the wave height. As previously referred this church is located $10 \mathrm{~m}$ above sea and the water rise $2.64 \mathrm{~m}$ inside the building. Another building, the Convento de São Francisco located, approximately, $7 \mathrm{~m}$

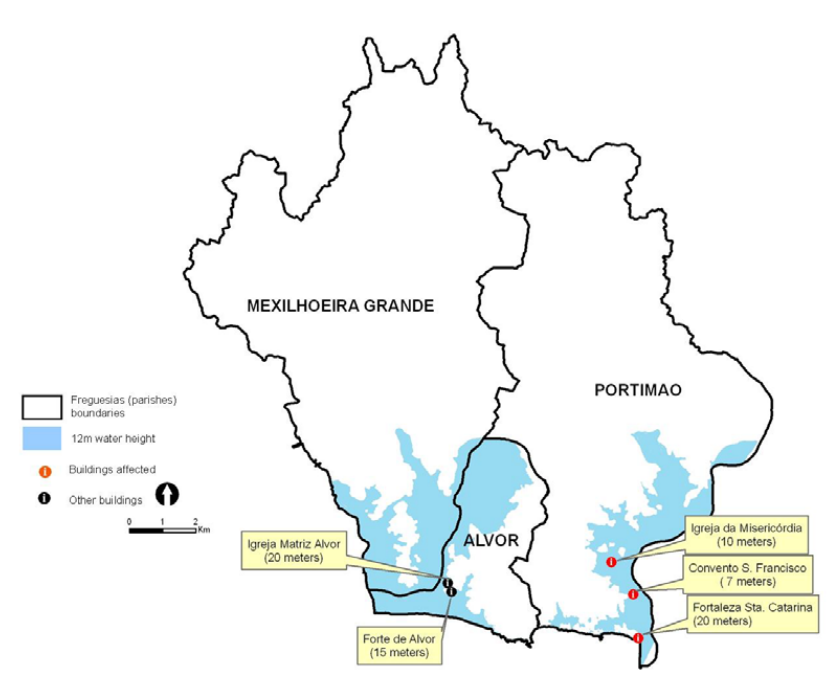

Fig. 2. Historial buildings location and the delimitation of the flooded area in municipality of Portimão as a consequence of the 1755 tsunami.

above the sea, was completely destroyed. These references were integrated in de map over the Digital Terrain Model (DTM). According to historical sources the height of $12 \mathrm{~m}$ was considered a reliable height for most of the wave but it is possible that in small areas the wave could have reached higher heights as it happened in Fortress of Santa Catarina located on a cliff edge. 


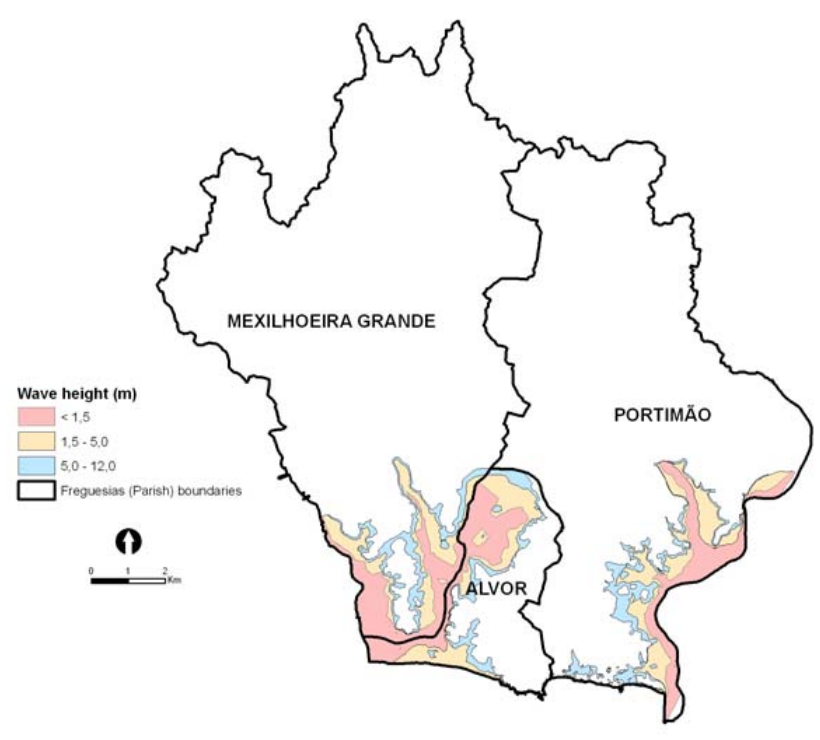

Fig. 3. The water height in 1755 tsunami: inverted model.

Based in the DTM, the lands with altitude below $12 \mathrm{~m}$ and near the coast had been identified, eliminating isolated areas surrounded by lands higher than $12 \mathrm{~m}$, producing a new DTM of the wave height (inverted) and in a polygon the flooded area (Fig. 3).

\section{The impacts of the 1755 tsunami nowadays}

The flooded area is inferred to have amounted to $23.75 \mathrm{~km}^{2}$, $13 \%$ of the total surface of the municipality. This extent is explained by the fact that this is a sandy coast with a reduced number of cliffs and by the existence of two rivers, natural boundaries of the municipality, serving as corridors allowing the advance of the waves.

Since 1755, two key factors have increased the vulnerability of Portimão. Seaside settlement is no longer solely based on local resources but on urbanization and tourism associated with the attraction of enjoying living and vacationing literally in front of the sea.

Nowadays, the potentially flooded area would put at risk approximately, 21845 inhabitants, according to 2001 Census data. The area most damaged would without a doubt be the low-lying area of the city of Portimão, affecting about 18303 people. In the others parishes fewer inhabitants would be in danger: 2403 inhabitants in Alvor and 1139 inhabitants in Mexilhoeira. Since Portimão is an area where tourism is the most important economic activity, we can conclude that the population at risk would actually be much higher. Although there is no statistical record of the temporary population and it varies tremendously during the year, if we take into consideration the water and electricity consumption in certain seasons, it is possible to say that the population doubles in some periods.
We estimate that approximately 5000 buildings would be affected, many of which would be destroyed or severely damaged, including hotels. However, the vulnerability of the hotel units is highly variable. We identified 67 hotels, of which 26 are located in the potentially flooded area. Some of the newest resorts are located in highly susceptible areas, as is the case of the hotel, restaurants and marina built in the mouth of the River Arade, which would represent the first structures to be struck by the waves of a tsunami.

In a disaster situation, the management of rescue means and security forces is essential. From our analysis, it is possible to conclude that with a wave height of $12 \mathrm{~m}$ the structures of civil protection agents would not be severely damaged. Only the police headquarters is located in a potentially flooded area but fire-fighter brigades and other security forces will not be affected.

When considering the health facilities, the primary care health centres would be affected but not the hospitals. However, also located in the potential flooded area are the airport, the prison, and the local building of Red Cross.

In addition, the road network itself would be severely affected and significant stretches of essential regional routes would either be flooded or destroyed.

We can thus conclude that faced with a tsunami similar to the 1755 event, the region would be considerably dependent on external rescue means.

These analyses are a summarised description of the virtuosity of our approach to emergency planning, although it is also possible to include other variables such as water and electricity infrastructures. They help us to demonstrate the population's exposure to risk and the urgent need to develop protection mechanisms, including a greater attention to land management efforts, especially as far as the location of priority equipment is concerned, but also the establishment of a building code, because if there have been tsunamis in the Algarve in the past, another tsunami could occur in the region in the future.

\section{Conclusions}

Although the average return period of a tsunami similar to the one that hit the Algarve in 1755 is very great, probably greater than 1000 years, it may occur at any time provided that the seismic source is totally or partially located in the sea and that the magnitude measures more than 7.5 (Costa et al., 2005). In that case a tsunami would rapidly arrive, meaning that a rapid recognition and reaction would be necessary to minimise the damage. In the 1755 event it is inferred that the tsunami arrival time is 7 to 16 min after the earthquake (Baptista et al., 1998, 2005). Thus, the delimitation of the flooded area is an important tool for emergency planning.

It is obvious that the simulation we present here is valid for an earthquake with the same magnitude and tectonic source as the 1755 event. Of course, other earthquakes with offshore 
epicentres but different magnitudes and locations will lead to distinct flood heights and inundated areas. In fact, the 28 February 1969 earthquake with a magnitude of 7.5 (Martins and Mendes-Victor, 2001) or 7.9 (Baptista et al., 1998) and epicentre on the Horseshoe Abyssal plain south of Gorringe Bank (Fukao, 1973) generated a weak tsunami that did not put at risk the coastal communities in the Algarve.

Although we have not used modulation to assess the energy of the tsunami, the simple identification of the flooded area is fundamental because the more extensive the area affected is, the higher the height of the wave and the energy transported are (Costa et al., 2005).

Also we must remember that run-up heights are not just a function of distance from the epicentre. In 1755 run-up heights were variable at similar distances from the epicentre. No doubt some of this variance reflects imprecision in the historical data but unlike the timing of onset, run-up height is a reasonably well constrained parameter in the historical record (Mendes et al., 1999). The configuration of the coast, state of the tide, and offshore bathymetry are also crucial factors.

We assess the potential impacts of a $12 \mathrm{~m}$ wave height but it is also possible to define several scenarios with obviously different impacts. The delimitation of the flooded area besides serving as a basis for the definition of scenarios and the determination of emergency planning tasks, may also serve as a guiding principle for land management.

Acknowledgements. The authors thank the Municipal Council of Portimão for providing cartography at 1:5000 scale, which was essential for the conduct of the research.

Edited by: P. Fabian

Reviewed by: D. Keefer and an anonymous referee

\section{References}

Baptista, M. A., Heitor, S., Miranda, J. M., Chierici, F., and Zitellini, N.: New study of the 1755 earthquake source based on multi-channel seismic survey data and tsunami modelling, Nat. Hazards Earth Syst. Sci., 3, 330-340, 2003, http://www.nat-hazards-earth-syst-sci.net/3/330/2003/.

Baptista, M. A., Heitor, S., Miranda, J. M., Miranda, P., and Victor, L. M.: The 1755 Lisbon tsunami; evaluation of the tsunami parameters, J. Geodyn., 25(2), 143-157, 1998.

Baptista, M. A.: Génese, impacte e propagação de Tsunamis na Costa Portuguesa, Tese de Doutoramento, Universidade de Lisboa, 1998.
Baptista, M. A., Heitor, S., Miranda, J. M., Miranda, P., Victor, L. M.: Constrains on the source of the 1755 Lisbon tsunami inferred from numerical modelling of historical data on the source of the 1755 Lisbon tsunami, J. Geodyn., 25(2), 159-174, 1998.

Baptista, M. A., Miranda, J. M., Chierici, F., and Zitellini, N.: New study of the 1755 earthquake source based on multi-channel seismic survey data and tsunami modelling, Nat. Hazards Earth Syst. Sci., 3, 333-340, 2003, http://www.nat-hazards-earth-syst-sci.net/3/333/2003/.

Baptista, M. A. and Miranda, J. M.: Evaluation of the 1755 earthquake source using tsunami modelling, Proceedings of International Conference 250th Anniversary of the 1755 Lisbon Earthquake, Lisboa, 574-577, 2005.

Carvalho, A., Campos Costa, A., and Oliveira, C. S.: A Finite Fault Modeling of the 1755 Lisbon Earthquake Sources, Proceedings of International Conference 250th Anniversary of the 1755 Lisbon Earthquake, Lisboa, 578-583, 2005.

Costa, A., Andrade, C., Seabra, C., Matias, L., Baptista, M. A., and Nunes, S.: 1755 Terramoto no Algarve, Centro Ciência Viva do Algarve, Faro, 2005.

Dicionário Geográfico, Freguesia de Alvor, Arquivo Nacional da Torre do Tombo, 3, 375-391, 1758.

Dicionário Geográfico, Freguesia de Vila Nova de Portimão, Arquivo Nacional da Torre do Tombo, 29, 1613-1628, 1758.

Dicionário Geográfico, Freguesia de Mexilhoeira Grande, Arquivo Nacional da Torre do Tombo, 23, 1053-1056, 1758.

Fukao, Y.: Thrust faulting at a lithospheric plate boundary. The Portugal earthquake of 1969, Earth Planet. Sci. Lett., 18, 205-216, 1973.

Gutscher, M. A.: What caused the Great Lisbon earthquake?, Science, 305, 1247-1248, 2004.

Gutscher, M. A.: Whodunnit in 1755? New clues from Sumatra, from the seafloor off SW Iberia and from GPS, Proceedings of International Conference 250th Anniversary of the 1755 Lisbon Earthquake, 568-573, Lisboa, 2005.

Martins, I. and Mendes-Victor, L.: Contribuição para o estudo da sismicidade da região oeste da Península Ibérica, Publicação no. 25, Universidade de Lisboa, Instituto Geofísico do Infante D. Luís, Lisboa, 2001.

Mendes-Victor, L., Ribeiro, A., Córdoba, D., Persoglia, S., Pellis, G., Sartori, R., Torelli, L., Zitellini, N., Dañbeitia, J. J., and BIGSETS Team: BIGSETS: Big sources of Earthquakes and Tsunami in SW Ibéria, Eos Trans AGU, Fall meeting, T12B-01, 1999.

Oliveira, F. X. A.: A Monografia de Alvor, Editora Algarve em Foco, 1907.

Lopes, J. B. S: Corografia ou Memória Económica, Estadística e Topográfica do Reino do Algarve, Lisboa, 1841.

Zitellini, N., Mendes, L. A., Cordoba, D., et al.: Source of 1755 Lisbon earthquake, tsunami investigated, EOS, 26, 285-291, 2001. 